\title{
Music as a Means to Accomplish Ideological Tasks: Pula (Istria, Croatia) in the Formative Years of Yugoslav Socialism (1947-1955) ${ }^{1}$
}

\author{
Lada DuRAKović \\ Music Academy, University of Juraj Dobrila in Pula \\ Rovinjska 14, 52100 Pula, Hrvatska \\ E-mail: lada.durakovic@gmail.com
}

(Received: September 2017; accepted: December 2017)

\begin{abstract}
After the signing of the Paris Peace Treaty in September 1947, Pula, a town in the south of the Istrian peninsula in Croatia, became a part of the People's Republic of Croatia and Yugoslavia. The period after the takeover of the city by the Communist authorities until the mid-1950s was marked by intense emigration, mostly of the Italian population, and also by re-industrialization and urbanization. At the same time, the process of forming art and culture according to the new ideological demands began. The instrumentalization of cultural life by ideology in the period between 1947 and 1955 left a significant trace on Pula's musical life. One of the main tasks of the authorities in the field of music culture was to promote musical education and popularize musical art, which was to be made available to a wider audience, especially labourers. The choice of music genres was narrowed significantly in order to ensure a close connection between the artist, his work, and the people. In the formative period of socialism in Pula, a music school opened, numerous cultural and artistic societies were established, operas were regularly performed at the theater and the Arena, and the city even had an operetta ensemble.
\end{abstract}

Keywords: music, Pula, ideology, socialist realism, Communism

During the early post-war, formative period (1945-1955), one of the primary tasks of the Yugoslav Communist government was to make the vision of "the socialist man" a reality. To effectively shape the new society, it was necessary to (re)form the citizens in accordance with the newly proclaimed values. Based on the theory of Marxism, "the socialist man" was supposed to be educated methodically and

1. This article is mostly based on my book Ideologija i glazbeni život: Pula od 1945. do 1966. god. [Ideology and musical life: Pula from 1945 to 1966] (Zagreb: Hrvatsko muzikološko društvo, 2011) and amended with the results of the research I performed subsequently. 
become a person active in a society where every person has the right to decent living conditions. It was believed that a society relieved of class antagonism and "exploitation of man by man" would be able to develop versatile "socially oriented socialist men who would fully contribute to the development of a new and more equitable society."2

The concept of building socialism excluded any possibility of a multiparty system and division of authority under the Communist Party rule. Authoritative power was effectively consolidated in the hands of Josip Broz Tito and the small circle of highest-ranking officials within the Politburo of the Central Committee of the Yugoslav Communist Party. The Communist Party created an overall political strategy, thus controlling internal, foreign, economic, and cultural policies. Political publicity was heavily used as a means of justifying every measure undertaken by the regime, with the aim of eliminating the capitalist system, and promoting a new order based on the principle of justice and equality for all members of the social community and all the peoples and nationalities of Yugoslavia. ${ }^{3}$ Appointed to leadership positions were those considered loyal to the Communist Party and politically correct, mainly young people from the working class and poorer social strata who - thus - became "the class predestined to lead" the new country. The country was to be proletarian and the regime, in contrast to the earlier periods, relied on lower social classes. In the early post-war years, the society was extremely focused on the Soviet Union, but after the clash with the Informbiro in 1948 and the first democratisation processes, the Communist ideology in Yugoslavia moved away from the Soviet model by introducing self-government. Perceived as a Yugoslav form of transition into Communism, it represented a specificity of the Yugoslav socialism in relation to the USSR and the countries of the so-called people's democracy. The disruption between Tito and Stalin resulted in Yugoslavia no longer being protected by the Soviet Union and, in turn, moving closer to the West, especially the United States of America. ${ }^{4}$

2. Ivan Hofman, "Osnovno i srednje obrazovanje u Jugoslaviji 1945-1952" [Primary and secondary education in Yugoslavia 1945-1952], in Kulturna politika Jugoslavije: 1945-1952 [Yugoslav cultural politics: 1945-1952], ed. B. Doknić (Beograd: Arhiv Jugoslavije 2009, 69), 68-93. For more on the concept of "the socialist man" in Yugoslavia, see: Stvaranje socijalističkoga čovjeka. Hrvatsko društvo i ideologija jugoslavenskoga socijalizma [Making of the socialist man. Croatian society and the ideology of Yugoslav socialism], ed. Igor Duda (Zagreb - Pula: Srednja Europa, Sveučilište Jurja Dobrile u Puli, 2017).

3. The Socialist Federal Republic of Yugoslavia was a federation made in the aftermath of World War II which existed until 1991. It was made up of six socialist republics: Croatia, Slovenia, Serbia, Bosnia and Herzegovina, Macedonia, Montenegro, and, in addition, included two autonomous provinces: Vojvodina and Kosovo.

4. For more on political and social processes of the early after-war period, see Igor Duda, "Uhodavanje socijalizma. Hrvatska u desetljeću poslije 1945. godine" [Running-in socialism. Croatia in the decade after the year 1945] in Refleksije vremena 1945-1955 [Reflections of the period 1945-1955], ed. Jasmina Bavoljak (Zagreb: Galerija Klovićevi dvori, 2013), 10-39; Zdenko Radelić, Hrvatska u Jugoslaviji 1945-1991. godine. Od zajedništva do razlaza [Croatia in Yugoslavia, 1945-1991: From unity to dissolution] (Zagreb: HIP - Školska knjiga, 2006); Ivo Goldstein, Hrvatska 1918-2008 [Croatia 1918-2008] (Zagreb: EPH Liber, 2008); Berislav Jandrić, Hrvatska pod crvenom zvijezdom [Croatia under the red star] (Zagreb: Srednja Europa, 2005). 
The then most significant political model of the USSR also largely determined the climate of the early post-war period. At the time, the priorities of the new society in the field of culture were reflected in the formation of an authentic socialist culture and art serving the proletariat. Through the activities of state and political organs and institutions, the Communist Party was thus working on the formation of a culture and art suitable for the form of social and political arrangement based on the rule of working people. The cultural policy on all levels was established in accordance with the principles of the socialist realism and the validation of social occurrences in line with the needs of the Party. Art was supposed to educate the youth, as well as contribute to the restoration and advancement of the country, and therefore, it had to be accessible to a broad range of consumers. A work of art was supposed to meet the criteria of socialist conceptuality (being accessible to the broadest masses), party affiliation (by promoting Communism), and the folk spirit (as opposed to cosmopolitism and bourgeois nationalism). ${ }^{5}$

The same applied to music, which was, prior to institutionalization of socialism, equally monopolized by the official, social artistic "elite." Hence, the tendency appeared to bring it closer to all walks of society whose cultural needs had been neglected in the past. Music was to reflect the basic categories of socialist realism, the idea was that music should not be a privilege of the elite, but a common good, and such thinking eliminated the understanding of music as an exclusively aesthetic formation. One of the main tasks was to ensure the ideological correctness of musical art. Art had to function as a part of the educational process in the struggle for socialist values. Musicians belonging to that period were expected to create works of art that reflected their attachment with their environment, and in this way, become the voice of their epoch. Their music was supposed to be "realistic in form" and "socialist in content." This meant within artistic practice a return to traditional stylistic forms and less sophisticated implementation of existing means of artistic creation. Relying on the theory of reflection, on the content level, the tendency within social realism was to glorify "proper" topics, such as the National Liberation Struggle (Narodnooslobodilačka borba), social consolidation and revolution. Particular importance was given to vocal music, or generally speaking, the kind of music that could be substantially linked to the mentioned subjects, such as mass songs, cantatas, theater music, etc. ${ }^{6}$

5. Jasmina Bavoljak, "Između diktata i savjesti" [Between dictation and conscience], in Refleksije vremena 1945-1955, 72-105. For more on cultural politics in the formative years of socialism: Ljiljana Kolešnik, Između Istoka i Zapada. Hrvatska umjetnost i likovna kritika 50-tih godina [Between East and West: Croatian art and art criticism of 1950s], (Zagreb: Institut za povijest umjetnosti, 2006); Branka Doknić, Kulturna politika Jugoslavije: 1945-1952 [Cultural politics of Yugoslavia: 1945-1952] (Beograd: Arhiv Jugoslavije, 2009).

6. For more on music and the socialist realism, see: Socialist Realism and Music, eds. Mikulaš Bek, Geoffrey Chew, and Petr Macek (= Colloquium Musicologicum Brunense 36, 2001) (Prague: Koniasch Latin Press, 2004); Nikša Gligo, Pojmovni vodič kroz glazbu 20. stoljeća s uputama za pravilnu uporabu pojmova [A guide through 20th-century music with instructions on the proper use of terms] (Zagreb: Muzički informativni centar Koncertne direkcije Zagreb, 1996), 262. 
The choice of music genres was thus limited and the technical means of composition simplified, all with the aim of ensuring the tightest possible connection between the artist, his work, and the people. The new doctrine did not approve of experimentation and every attempt of "modernist deviance" was considered a bourgeois subversion. ${ }^{7}$ The capitalist West was described using stigmatizing metaphors, and principles the decadent West applied in music were similarly devalued as ideologically incorrect.

A strong institutionalization of all forms of artistic production and national edification was a political imperative. In order to ensure such tendencies within the cultural domain, it was essential to establish an organizational system which would guarantee the implementation of the ideologically outlined cultural policy. The Agitprop - Department of Agitation and Propaganda, operating under the Central Committee of the Yugoslav Communist Party - was therefore given the authority to control and direct all intellectual activities, including music production, in accordance with the given political and party line. In addition, Agitprop monitored the work of the state bodies which had authority over cultural activities, thus influencing the (lack of) freedom of artistic expression. ${ }^{8}$

The Agitprop of the Central Committee of the Communist Party of Yugoslavia was led by Milovan Đilas, a member of the Politburo and one of Josip Broz Tito's closest associates and ideologists. The highest ranking positions in this organization were filled according to strict cadre policy, with people enjoying absolute trust of the party leadership. The Agitprop consisted of separate committees, which were divided into sectors. The cultural-artistic committee of the Agitprop in Croatia, then forming part of socialist Yugoslavia, was led by Marin Franičević, and it consisted of the literature, music and art sectors, the national enlightenment sector, the cultural-educational societies sector, and the film and theater sector. The music sector was led by the prominent Croatian composer Natko Devčić. ${ }^{9}$ He was

7. Ivo Kirigin, "O potrebi muzičke kritike i njezinim zadacima" [On the necessity of music criticism and its tasks], Muzička revija 1 (1950), 13-38.

8. For more on the Agitprop's role in art and culture, see Ljubodrag Dimić, Agitprop kultura. Agitpropovska faza kulturne politike u Srbiji [Agitprop culture. The Agitprop phase in the cultural policy of Serbia] (Belgrade: Rad, 1988); Tatjana Šarić, "Djelovanje Agitpropa prema književnom radu i izdavaštvu u NRH, 1945-1952" [Activity of the Agitprop in regard to literary work and publishing in the People's Republic of Croatia in 1945-1952], Radovi-Zavod za hrvatsku povijest 42 (2010), 387-424; Magdalena Najbar-Agičić, Kultura, znanost, ideologija: Prilozi istraživanju politike komunističkih vlasti u Hrvatskoj od 1945. do 1960. na polju kulture $i$ znanosti [Culture, science, ideology. Contributions to the research of the policy of the Communist government in Croatia from 1945 to 1960 in the fields of culture and science] (Zagreb: Matica hrvatska, 2013).

9. Croatian composer, music teacher, and music writer Natko Devčić (1914-1997) obtained his degree in piano and composition from the Zagreb Music Academy in 1937. As a student, he also lived in Paris, Darmstadt, and the USA. From 1947 until 1980, he was a professor at the Music Academy in Zagreb, and, since 1992, he was a regular member of the Croatian Academy of Sciences and Arts. He received numerous awards and recognitions. Folklore was a constant source of inspiration in Devčić's lifework. At the end of the 1960s, he started exploring more recent composition practices (electronic music, experimental treatment of vocals, new articulation on traditional music instruments, etc.). He authored a textbook entitled Harmonija [Harmony] $\left({ }^{1} 1975,{ }^{2} 1993\right)$. For more, visit http://www.enciklopedija.hr/natuknica.aspx?id=14861 (last accessed on 13 September 2017). 
in charge of monitoring the activities of the Composers' Association (Udruženje kompozitora), the Reproductive Artists' Association (Udruženje reproduktivnih umjetnika), Conservatory and music schools, the Croatian Music Institute (Hrvatski glazbeni zavod), the Music Publishing Organization (Muzička naklada), as well as concert organization, and radio broadcasts. He also held meetings with editors of culture sections in contemporary media and granted approval to music critical reviews. ${ }^{10}$

The priority in the music area was education, and as a result, music schools were opened across the country, despite the shortage of qualified teaching staff. Literature on classical music, which was for a long time available only to the privileged layer of society, was supposed to be used by young people as an introduction to "great music artists" whose artwork contained a humane message and supported the thesis that music was a strong tool in the struggle for the transformation of society. ${ }^{11}$ Another development that was not hindered by the lack of educated human resources was the establishment of numerous music societies and orchestras, which often operated without proper instruments and under the leadership of underqualified conductors. Furthermore, an extensive network of Cultural and Art Boards (Kulturno-umjetnički odbori) was created to control the country's cultural life, organize concerts, symposiums and congresses. To make classical music more popular, their members helped musicians by offering them advice and material assistance, supplying them with selected scores, instructing them in choosing their repertoires, arranging concert events, and so on. Since it was believed that the social composition of professional musicians would change in the future, the boards were also in charge of assisting young musical talents from the lower classes that had not been given the opportunity to receive music education and develop their abilities. They also organized courses aimed to educate the ranks of new music managers. ${ }^{12}$

The widespread Concert Offices (Koncertne poslovnice) were another important agent in implementation of the cultural policies the national Government put forth. Their task was to organize not only concerts but also cultural and artistic events in concert halls and factories, mines, big construction areas, trade-union halls, etc. Their most important task, however, was their cultural-educational work, aimed at systematic familiarization of people from all walks of society with art music, and to enable their cultural uplifting in this way. ${ }^{13}$

10. Šarić, “Djelovanje Agitpropa prema književnom radu i izdavaštvu u NRH 1945-1952,” 387-424.

11. Lada Duraković, “"Educate for Music, Educate by Virtue of Music.' Music Education in Primary Schools in Early Socialism - the Case of Croatia," Südost-Forschungen 76/1 (December 2017), $24-42$.

12. See for example Miroslav Špiler, "O Glazbi. Prvi kongres kulturnih radnika Hrvatske, Topusko 1944" [About music. The first congress of cultural workers in Croatia, Topusko 1944], Časopis za suvremenu povijest 8/2-3 (1976), 1-150.

13. Ladislav Šaban, 150 godina Hrvatskog glazbenog Zavoda [150 years of the Croatian Music Institute] (Zagreb: Hrvatski glazbeni zavod, 1982). 
The media were also engaged in the promotion of the musical art. The music reviews published in newspapers and magazines were usually written by individuals whom the party designated for such tasks. They were expected to provide clear and easy-to-understand interpretations of the performed works and to do so consistently in line with the teachings of Marxism-Leninism. ${ }^{14}$

Given that the public had to be primarily educated, one of the most important features of music journalism discourse was its didacticism and activist engagement. ${ }^{15}$ The task of the critic was to encourage the artists to serve their people and the generally proclaimed interests. As for performers, the tendency was to influence their character and style of performance, as well as the choice and structure of the programme, which had to cater not only the performers' tastes and abilities, but also the needs of the people whom certain shows and concerts were intended for. ${ }^{16}$ Music criticism often contained sharp comments of how well a work of art fitted the ideological schemes. "Formalism and decadence" in music were especially under attack, but these were usually unsubstantiated, without clearly pointing at actual faults, or displaying arguments for the supposed low quality of Western contemporary music. ${ }^{17}$

In the 1950s, the cultural arena in Croatia witnessed a change in perspective as a different set of opinions began to form. After the Workers' Self-Management Act (Zakon o radničkom upravljanju) was passed, the idea came about that, for the realization of a self-managing society, it was necessary to strengthen the foundations of culture, and that a complete development of the society in fact depended to a certain extent on numerous culture-related forces. The cultural sector was largely left to the so-called "culture workers" under the condition that appropriate norms were respected. ${ }^{18}$

The first half of the 1950s was marked by the creation of a new cultural-artistic identity. Although the music production of the period shows no clear innovative breakthroughs such as those in fine art and literature, ${ }^{19}$ artistic initiatives flared

14. The situation in the post-war cultural politics in the area of music is best described by texts published in contemporary specialized music magazines and reviews. In the period between 1945 and 1952 the following publications were released in Croatia: Muzičke novine [The Music Newspapers] (Zagreb: Hrvatski državni konzervatorij, Hrvatski glazbeni zavod 1946-1948), Muzička revija [The Music Review] (Zagreb: Zora, 19501951), and Muzičke novine [The Music Newspapers] (Zagreb: Savez muzičkih udruženja, 1951-1952).

15. Milan Milojković, Analiza jezika napisa o muzici. Srbija u Jugoslaviji 1946-1975 [An analysis of the discourse of writings on music. Serbia in Yugoslavia, 1946-1975] (Novi Sad: Akademija umetnosti, 2013).

16. Ivo Kirigin, "O potrebi muzičke kritike i njezinim zadacima" [On the necessity of music criticism and its tasks], Muzička revija 1 (1950), 13-38.

17. Silvije Bombardelli, Extempore (Split: Čakavski sabor, 1973).

18. Zdenko Radelić, Sindikat i radništvo u Hrvatskoj 1945-1950 [Trade union and working class in Croatia 1945-1950] (Zagreb: Hrvatski institut za povijest, 2012); Sharon Zukin, Beyond Marx and Tito. Theory and Practice in Yugoslav Socialism (Cambridge: Cambridge University Press, 1975).

19. For more on the significant instances of stepping forward into the contemporary concept of art, in the field of fine art and literature, see: Ljiljana, Kolešnik, "EXAT'51," in Hrvatska umjetnost: povijest i spomenici [Art in Croatia. History and monuments ], ed. Pelc Milan (Zagreb: Institut za povijest umjetnosti, Školska knjiga, 2010), 667-671; Krugovi i hrvatska književnost pedesetih godina prošlog stoljeća [The journal "Krugovi" 
up and spread out extensively, which had an impact on the musical life as well. ${ }^{20}$ This is evidenced by the gradual stepping away from the concepts of socialist realism and opening up to various music practices of Western provenance, especially popular music which began to strengthen its presence and increase its symbolic influence. ${ }^{21}$ Consequently, a considerable number of valuable works of art was produced, while aesthetic restrictions gradually diminished.

\section{"Music for the people" in Pula Activity of local musicians - cultural-artistic work and music creativity}

Pula, a town on the south of the Istrian peninsula in Croatia was during the twentieth century under the authority of different ideological characteristics and divergent articulations. The town enjoyed the reputation of a music centre, building its urban character on a carefully cultivated musical tradition. What we call today the city's musical identity is to a large extent the result of the interweaving of various influences and legacies of former cultures, nations, and the personalities who lived in this area. In the nineteenth century and at the beginning of the twentieth century (until 1918), Pula was the main Austro-Hungarian military port where a permanent professional musical body performed - the orchestra of the Royal and Imperial Navy. Along with operas and operettas, some singing and instrumental competitions were held in the Politeama Ciscutti theater, as well as dance and charity performances. Two music schools were active in the city: the City Music School (Scuola cittadina di musica) and the Scuola accademica di musica. During the Italian rule (1920-1943), operas and operettas were put on in the theater in cooperation with the opera houses and operetta troupes from larger Italian music centres, mostly from the Friuli Venezia Giulia region. Along with theater shows, from 1932 to the fall of fascism, musical and stage works were shown in the open air, in the amphitheater, too. Artists from various Italian opera houses performed and operas of Italian composers usually featured. In 1927 the Music Lyceum "Rossini" was founded (as a branch of the "Gioacchino Rossini" Acade-

and Croatian literature in the 1950s], ed. Mirko Tomasović and Vinka Glunčić-Bužančić (Split: Književni krug, 2003).

20. For more on music composition in the 1950s in Croatia and the positioning of composers in relation to art practices in the West see: Eva Sedak, "Glazba pedesetih godina" [The 1950s in music] in Pedesete godine u hrvatskoj umjetnosti [The 1950s in Croatian art], eds. Zvonko Maković and Iva Radmila Janković (Zagreb: Hrvatsko društvo likovnih umjetnika, 2004), 190-201.

21. For more on the affirmation of popular music see, for example: Maša Kolanović, "Od kulture za mase do masovne culture" [From mass culture to culture for the masses], in Refleksije vremena 1945-1955, 166179; Radina Vučetić, Kokakola socijalizam. Amerikanizacija jugoslovenske popularne culture šezdesetih godina XX veka [Coca-Cola socialism: Americanization of Yugoslav culture in the 1960s] (Beograd: Službeni glasnik, 2012). 
my of Trieste), and it was active until 1936. Musical events did not come to an end at the time of the Anglo-American military administration (1945-1947) either, but were especially intensified after the annexation of Istria to Croatia, i.e. Yugoslavia (from 1947 to the Croatian independence in 1991) of the time. ${ }^{22}$

After the two-year Anglo-American military administration ended, and the Paris Peace Treaty regulations came into force in September 1947, Pula became a part of the People's Republic of Croatia and Yugoslavia. Along with the problems that came along with the constitution of the new governance, its post-war reality was noticeably marked by the great exodus of a part of the autochthonous population. The loss of a large number of citizens left a deep mark on the face of the town, and the institutions which could have maintained its identity were no longer in operation. The largest number of citizens - mostly Istrian Italians - emigrated to several Italian regions, leaving Pula for the second time in the twentieth century without the bulk of its citizens, those who had embedded in their town their aspirations and energy, thus shaping it according to their needs. They were substituted by new citizens who brought different visions of the town's development and social behavior. ${ }^{23}$

With people from different parts of Yugoslavia settling in Pula, the population structure in the city changed profoundly, and as a result of their varied, often non-urban backgrounds, their cultural demands were hugely divergent. It appeared that many of them needed to become culturally socialized, "urbanized," as it were.

The Communist Party, which was completely integrated into the state apparatus in the early post-war years, started applying the same model of rule in the new part of the state territory. The cultural and artistic life in Pula was subordinate not only to the state, but also to the daily local politics, and the cultural events that were advanced and promoted were those that had the best chance of communicating political messages. The role of culture was "agitation and propaganda" of the new authorities and ideology:

22. For more on Pula's music life in the first half of the twentieth century see my studies, for example: Lada Duraković, Pulski glazbeni život u razdoblju fašističke diktature 1926-1943 [The musical life in Pula under the fascist dictatorship 1926-1943] (Zagreb: Hrvatsko muzikološko društvo, 2003); eadem, "Music at on the Threshold of World War I: Pula 1914," in The 9th International Symposium "Music in Society," ed. Fatima Hadžić (Sarajevo: University of Sarajevo, Academy of Music, 2017), 99-121; eadem, "Music in the Austro-Hungarian Monarchy Period: Multinational Musical Identity of the Town of Pula in the Beginning of the 20th Century," in 7th International Symposium "Music in Society,” ed. Fatima Hadžić (Sarajevo: Muzička akademija u Sarajevu, 2012), 94-108.

23. For a comprehensive overview of Pula in the twentieth century, see some of the numerous studies and monographies by Darko Dukovski, such as: Povijest Pule: deterministički kaos i jahači apokalipse [History of Pula: Deterministic chaos and the horsemen of the Apocalypse] (Pula: Istarski ogranak DHK, 2011); idem, "Pula XX stoljeća: uzroci promjene identiteta" [Twentieth-century Pula: The causes of identity change], in Pula 3000, eds. Emilio Cvek, and Attilio Krizmanić (Pula: C.A.S.H., 2004), 57-80. 
In order to ensure the success of our efforts, cultural events must be carefully selected. They should reflect the contemporary spirit. They must be ideological-cultural or entirely artistic in nature. The goal is to cherish the love and brotherhood among our nations, and the revolutionary spirit of Marx, Engels, Lenin, and Stalin. ${ }^{24}$

The culture "for the people and from the people," the universal, socialist culture tailored to the needs of the "socialist man" was designed in the Agitprop of the Pula Party Committee. ${ }^{25}$ Led by the Party directives, the people's authority in Pula took care of the overall improvement of education, culture, and cultural-artistic life. The people were offered the possibility to actively participate and work in the cultural-artistic domain and to educate themselves in the newly founded schools, courses and seminars. Kindergartens, nurseries, primary and secondary schools, workers' adult education schools, museums and libraries were opened.

The Socialist Realism and its ideas were faithfully reflected in the effort to transform the musical life, while one of the most significant characteristics was the so called "edification" or "enlightenment" approach - bringing musical art closer to a wider circle of recipients, to new citizens with a "low" cultural standard. Soon after the annexation to Croatia and Yugoslavia, in the first half of the year 1948, male and mixed choirs were actively performing in Pula, in addition to the choirs of the Croatian and Italian Gymnasium and of the Railway Technical College (Željeznički tehnikum), as well as the Town's Orchestra and the economy students' fanfare ensemble (ansambl fanfara učenika u privredi). The Agitprop department of the City committee regularly received reports about all music events it monitored and directed, containing data about the number of active singers and musicians at a certain music event, the exact number of concerts, and including details about their programmes, how politically appropriate the repertoire was, how many tickets were sold, etc. ${ }^{26}$ Since the tendency was to provide workers with musical education, the events were followed by lectures, while guest musicians and ensembles performed in factories, mines, and hospitals in order to introduce the music to the workers in an environment that was close and familiar to them. However, since workers did not show sufficient interest for music events, they were obligated to attend such events organized within their work premises.

24. "Da bi rad što bolje uspijevao, potrebno je birati programe. Programi treba da odgovaraju duhu sadašnjice. Moraju biti ideološko-kulturni ili potpuno umjetnički. Cilj je njegovati ljubav i bratstvo neđu narodima i revolucionarni duh Marksa i Engelsa, Lenjina i Staljina”. The State Archives in Pazin, HR-DAPA-114, 289. Official transcript of Josip Ravnić's statement made at the meeting of cultural educational associations, dated 26. September 1948.

25. The Agitprop of the District Committee of the Communist Party of Croatia was located in Rijeka and managed by Dina Zlatić.

26. Numerous reports on the work of various cultural institutions (theaters, cultural and artistic societies and offices) that were sent to Agitprop for verification and approval can be found at the State Archives in Pazin: HR- DAPA-114, 289. fragments, 1947; HR-DAPA-114, 291, Reports on Cultural and Public Work. 
For example, a theatrical ensemble performed at several companies, special opera performances were organized for workers, while the town's choirs and cultural-artistic associations regularly held concerts in factory halls (Plate 1). ${ }^{27}$

Plate 1 Poster of a concert given by the Matko Brajša Rašan choir, joined by the City Orchestra, in 1954. (Source: Pula University Library)

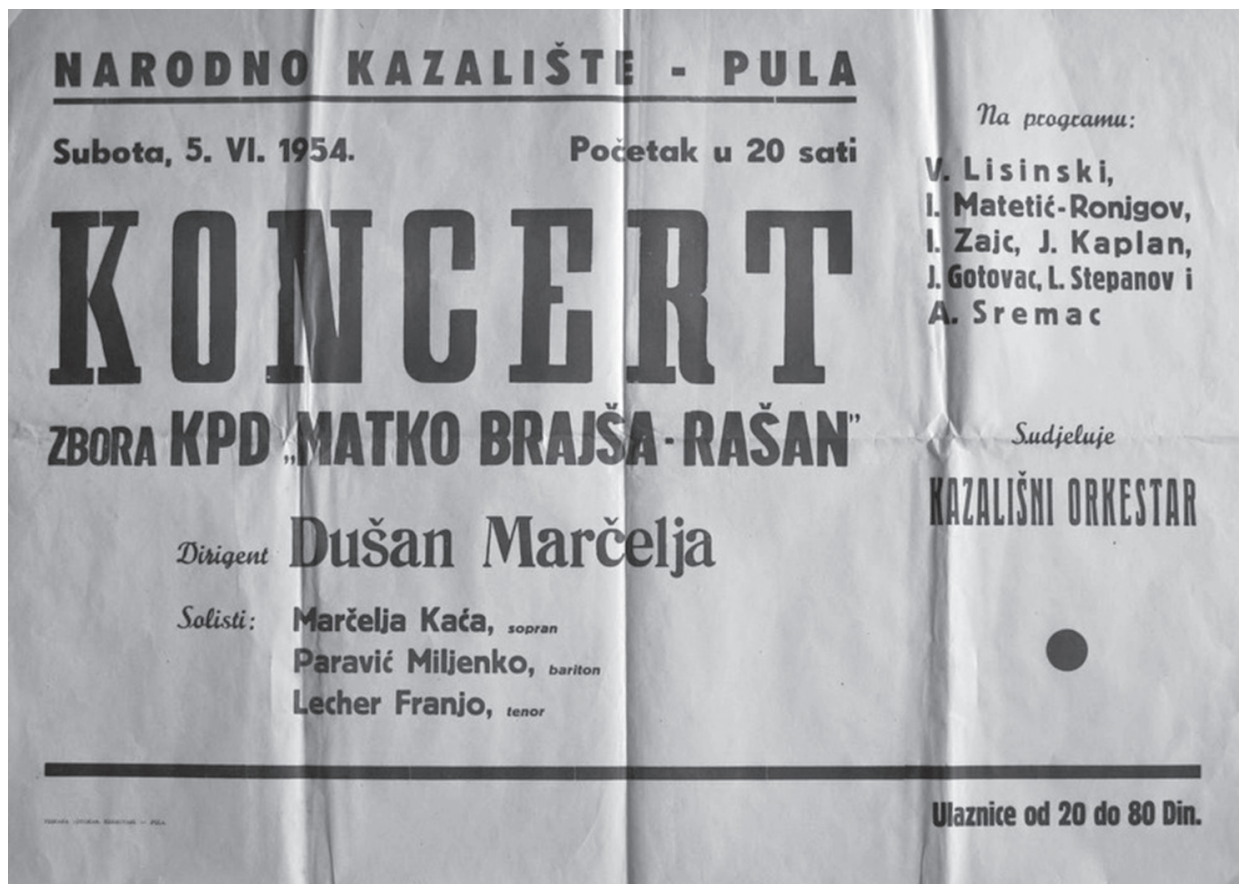

Cultural-artistic associations were founded in towns and their goal was to demonstrate through their work and performances the loyalty of their members to the new government, and appreciation of folk art.

The role of the society is to actively participate in creating new, genuine, and uninhibited people's art, one that evolves from our national liberation movement, that is closely intertwined with the interests of our proletariat on the largest possible scale ... to engage in such cultural-artistic endeavours so as to contribute to the power and progress of F.P.R. Yugoslavia and its peoples' democratic government, to advance true brotherhood and friendship among its peoples, heroic fight for freedom and national prosperity, loyalty and love for

27. Documented records of the activities conducted by the cultural-artistic societies are kept in the headquarters of the Cultural-Artistic Association "Matko Brajša Rašan" and the Workers' Cultural-Artistic Association "Lino Mariani," both in Pula. 
the country and the people ... to be in the service of spreading and reaffirming the unity and solidarity of the proletariat $\ldots{ }^{28}$

However, behind the seemingly empty demagogical and agitating significance of music which was supposed to impact people in view of their ideological-political enlightenment, in the 1950s, positive trends were noticeable in Pula's music life that eventually turned out to be very important. Cultural-artistic societies were established, and still operate successfully. The repertoire politics broadened the prior performing horizons and contributed to music creation.

The creation of original musical pieces was the most critical issue in the early post-war period. Professional musicians who were active during the Italian rule were scarce anyway, and most of them left Pula after the war. Those who stayed did not leave a significant trace. Among the newly arrived population, coming from different parts of Yugoslavia, only a handful had music education or composing abilities for that matter.

Two composers whose work made an impact are Zlatko Špoljar ${ }^{29}$ and Josip Kaplan. ${ }^{30}$ During his stay in Pula, Zlatko Špoljar was committed to writing children choir songs and stage music for school plays. The work of Josip Kaplan was very diverse, while his most popular pieces are numerous mass songs, speaking of national liberation struggles and post-war restoration, commonly found in the repertoire of school choirs and cultural-artistic associations in Pula.

As a result of such modest creative production, it is difficult to determine how well it reflected the changes that took place in the $1950 \mathrm{~s}$, or to which extent single composers escaped ideological arbitrage and managed to achieve aesthetic autonomy. The authors did not show any affinity for the more complex genres, nor for any stepping forward into the "new" and the "avant-garde." There were no

28. "Zadaće društva su da aktivno učestvuju u razvijanju nove, istinske i slobodne narodne umjetnosti, koja je nikla iz oslobodilačke borbe naših naroda i koja je usko povezana s interesima najširih radnih narodnih masa ... da kulturno umjetničkim radom pomaže izgradnju i učvršćenje FNR Jugoslavije i njene narodne demokratske vlasti, da razvija istinsko bratstvo i drugarstvo naroda, heroizam u borbi za slobodu i narodno blagostanje, odanost i ljubav prema domovini i narodu ... da služi širenju i učvršćivanju jedinstva i solidarnosti radničke klase ...". The State Archives in Pazin, HR-DAPA-114, 289. [Work regulations for cultural-artistic associations, 1949].

29. Teacher and composer, Zlatko Špoljar (1892-1981) worked in Pula as a teacher at the Teachers' College from 1947 to 1952. His legacy, kept in Rijeka State Archives, consists of handwritten music sheets of the pieces he composed. Unfortunately, most of these are not dated, so it remains unclear which of these he composed during his stay in Pula. Cf.: Zorica Manojlović, Ostavština Zlatka Špoljara u Državnom arhivu u Rijeci [The Legacy of Zlatko Špoljar in the Rijeka State Archives], 2014. http://lartis.net/arhol2/ostavstina-zlatka-spoljara-u-drzavnom-arhivu-u-rijeci/ (last accessed on 13 September 2017).

30. Composer, choir leader, and teacher, Josip Kaplan (1910-1996) worked as a teacher at the Teachers' College and at the Music School, and as a choir leader in cultural-artistic associations. In his monograph, the music writer and publicist Andrija Tomašek lists Kaplan's musical pieces, among which he mentions those composed between 1949 and 1959, namely, choir songs and chamber ensemble pieces. Since Kaplan did not spend this decade only in Pula, it is not clear which pieces were in fact composed during this time. Andrija Tomašek, Josip Kaplan. Skica umjetničkog portreta [Josip Kaplan. The outline of an artistic portrait] (Zagreb: Kulturno-prosvjetni sabor Hrvatske, 1986). 
performers in the city who would have been able to perform such works, and, in addition, the unprepared audience could not have been expected to accept them. The small number of urban intellectuals was mostly raised to respect the values of serious music, which the less educated citizens still needed to get accustomed to.

\section{Music education}

Communist authorities assigned great importance to music education, as they considered it an efficient means of bringing this art closer to young people from poorer, working class families. School choirs were assembled in schools, especially in the Croatian Gymnasium, which also organized school orchestra performances for special occasions, and the same practice was similarly upheld in the Italian Gymnasium and in the Teachers' College (Učiteljska škola). ${ }^{31}$ In 1949, following a years-long interruption in the continuity of institutionalized music education in Pula, the Music School was officially opened following the decision of the People's City Board.

For the first time, Pula got not only a publicly available, free music school, but also a school providing music education to working class children. The need for such an institution in a city with such a high proportion of children is obvious, but it is important to highlight the fact that establishing such an institution is possible only in a socialist society, where education and cultural enlightenment is not a prerogative of just one class, but rather a right of each member of the social community, and it is the responsibility of public authorities to enforce that right. ${ }^{32}$

In the course of the first few years, any citizen of Pula who had any kind of music knowledge could become a member of the teaching staff there. The curriculum included piano, violin, cello, trumpet, clarinet, horn, and singing lessons. Shortly after, flute, trombone, and double bass lessons were introduced and a choir was organized. In the first post-war years, the Music School accepted almost all interested attendants because it was commonly viewed that higher education of young people would help not only the performing activities, but also the work of cultural-artistic associations and other cultural and educational organisations. The

31. Records of some of the music activities in schools are kept in the archives of the Pula Gymnasium.

32. "Pula je tako po prvi put dobila ne samo javnu i besplatnu Muzičku školu nego i školu u kojoj mogu učiti muziku i radnička djeca. Potrebu takve ustanove u gradu gdje ima toliki broj djece bilo bi suvišno isticati, ali treba podvući da je takva ustanova moguća samo u socijalističkom društvu gdje školovanje i kulturno uzdizanje nije privilegij jedne klase, nego pravo svakog člana društvene zajednice i dužnost narodnih vlasti je da mu to omoguće." No author, "Muzička škola u Puli započela je s radom" [The Music School in Pula began to operate], Riječki list (9 March 1949), 3. 
number of classrooms and the amount of space was insufficient. The most serious problem concerning the teaching staff was the lack of a qualified violin teacher: along with the piano lessons, violin lessons were in highest demand. Teachers of theoretical subjects were also lacking. Classes in music history required lectures accompanied by sound clips, but the school did not have gramophone records or tape recorders and it did not own a concert piano either. In spite of all these inadequacies, public productions were regularly held in the school (see Plate 2), with full media coverage and appraisal of its work. ${ }^{33}$

\title{
Theatrical-musical activity: the National Theater and the Amphitheater
}

The National Theater was opened in January 1949. This institution also experienced numerous problems. The theater building was in a very poor condition, and the only piece of stage equipment available was an iron curtain, while everything else was blown up and demolished after the departure of the Anglo-Americans. The attitude of the political establishment in this regard was that the theater must become the property of the people, a place of cultural education for all social classes. ${ }^{34}$

\begin{abstract}
Every worker in Yugoslavia has the right and the responsibility to take part in the domain of culture, to read, learn, attend cinematic and theater performances, to engage in music, literature, and other artistic endeavours. This performance is not attended by an audience wearing evening dresses and black ties ... This is not a dispassionate, passive audience, but a crowd of spectators who engage in every performance on stage with their whole being, thankful to do people's government who made this experience possible for them. ${ }^{35}$
\end{abstract}

33. Lada Duraković, "Prvih 15 godina rada Muzičke škole u Puli 1949-1964" [The first 15 years of the Music School in Pula 1949-1964], in Slavko Zlatić: 100. obljetnica rođenja [Slavko Zlatić: 100th anniversary of his birth], eds. Ivana Paula Gortan-Carlin and Mirna Marić (Novigrad: Katedra Čakavskog sabora za glazbu 2013), 119-133. More information at the Archives of the Ivan Matetić Ronjgov Music School in Pula; the State Archives in Pazin: HR-DAPA-93, 44, Zavod za školstvo Pula [Documents about the activity of the Pula Music School].

34. Miljenko Paravić, Put kojim smo prošli: Pet godina Narodnog kazališta u Puli. 1949-1954 [What we have been through: Five years of the National Theater in Pula. 1949-1954] (Pula: Sindikalna podružnica Narodnog kazališta, 1954.)

35. "U socijalističkoj Jugoslaviji svaki radnik ima pravo i dužnost da se svestrano uzdiže, da čita, uči, posjećuje kino i kazalište, da se bavi glazbom, književnošću i umjetnošću. Na ovoj predstavi nema publike u crnim frakovima i večernjim haljinama ....nije to blazirana publika koja se dosađuje na predstavi, već su to gledaoci koji sudjeluju u svakoj izvedbi svim svojim bićem, zahvalni narodnoj vlasti koja im je to omogućila." No author, "Svoju uspješnu turneju završila je riječka opera u Raši”" [The Rijeka Opera House completed a successful tour in Raša], Glas Istre (25 December 1949), 3. 
Plate 2 Poster of a concert held during the first year of existence of the City Music School in Pula

\section{GRADSKA MUZIČKA ŠKOLA - PULA SCUOLA CITTADINA DI MUSICA - POLA}

\section{NARODNO KAZALISTE TEATRO DEL POPOLO U T O R A K 31: X. 1950. 0. MARTE D I 31 X. 1950 PRIREDBA RAPPRESENTAZIONE}

u čast izbora zá Sabor N.R.H. - in onore alle elezioni per il Sabor della R.P.C.

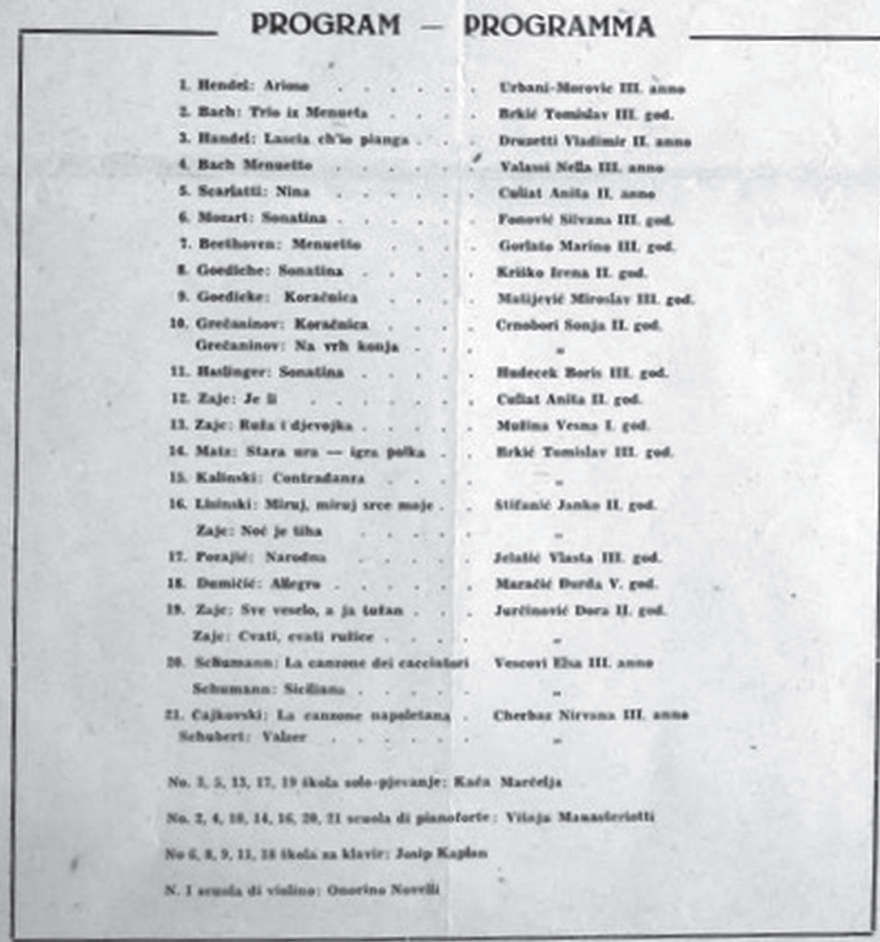

Početak u 18 sati. - Inizio alle ore 18. 
The influence of political turmoil in the musical area was least prominent in the theatrical domain. The ideological discourse about the cultural policy often emphasized the societal function of the theater, its task to contribute to the construction of socialist relations, and the need for accessibility as one of the criteria in selecting the musical stage pieces that formed the repertoire. Newspaper articles, announcements and reviews of opera and operetta performances never failed to make special mention of the city officials, who "honored" the musical stage performance with their presence. This was especially the case when a concert was organized as a part of a political event, but politics did not directly intervene in programme selection.

During the first post-war years, many musical stage programmes and guest performances of cultural-artistic associations from different parts of Yugoslavia were staged in the National Theater. Especially significant was the 1949 production of Mala Floramye [Little Floramye], an operetta by the Croatian composer from Split, Ivo Tijardović, ${ }^{36}$ as this was the first instance of a music piece being staged entirely by the theater's own ensemble. Only two solo performers were hired from the near-by older Rijeka National Theater, whereas the rest of them were amateurs from Pula. The performance was staged and performed under the leadership of Dušan Marčelja. ${ }^{37}$

After the success of this performance, in the following years several other operettas were put on stage as independent productions, among which Franz Lehár's Ševa [Where the Lark Sings] and Zemlja smiješka [The Land of Smiles]. In 1952, the theater's direction encouraged by the success of these productions decided to found - for the first and the last time in its history - a musical stage and operetta ensemble. Local amateur singers, theater actors and members of different cultur-

36. Croatian composer and conductor Ivo Tijardović (1895-1976) studied music in Split and Vienna and graduated from the School of Drama in Zagreb in 1922. He excelled as an organizer, scenographer, painter, and illustrator. He was director of the Opera and head of the Split Croatian National Theater (1933-1941), later head of the Zagreb Croatian National Theater (1945-1949) and director of the National Symphonic Orchestra (1949-1954). He composed music for various ensembles (orchestral and chamber, solo voices, choir) as well as film music. However, his primary field of interest was composing theater music, especially operettas, the most successful of which were Mala Floramye [Little Floramye] (1926) and Splitski akvarel [Split Aquarel] (1928). His librettos, some of which he personally authored, were mostly connected thematically to the Mediterranean and the Dalmatian expression, Split especially. His aesthetics as a composer was mostly focused on tradition, and relied on folklore and the national music idiom. Cf.: http://www.enciklopedija.hr/natuknica. aspx?id=61296; http://www.hds.hr/clan/tijardovic-ivo/ (last accessed on 13 September 2017).

37. Conductor and music educator Dušan Marčelja (1908-1990) started his piano study at the Conservatory in Trieste, and finished it at the Zagreb Music Academy in 1932. He spent the period from 1934 to 1942 in Vinkovci working as a grammar-school professor and choirmaster of the Vocal Ensemble "Reljković." After that, he taught at the Teachers' School in Sarajevo (1943-1945) and managed a music school and the choir of Radio Sarajevo. From 1940 until 1948, he was an accompanist and choirmaster at the Rijeka Opera. Since 1948, in Pula, he conducted operetta performances in the Istrian National Theater, taught at the Teachers' School and at the Music School where he was also the director (1949-1952). He worked in Rijeka again between 1959 and 1977, at the Opera of the National Theater "Ivan Zajc" and managed the choirs Jedinstvo [Unity] and Fratellanza. Cf.: http://www.istrapedia.hr/hrv/2749/marcelja-dusan/istra-a-z/ (last accessed on 13 September 2017). 
al-artistic associations tried their skills in vocal roles, while the orchestra consisted of permanent members, as well as guest instrumentalists.

The enthusiasm of these amateur performers, the persistence and devotion they displayed during rehearsals, and the success the productions achieved clearly demonstrate the capacity and the ability these working people have when it comes to cultural-artistic expression, in terms of both vocal and instrumental performance ... Thanks to the support of our people's government, its commitment to removing any obstacles, Pula has become a city of huge cultural and artistic potential, led by those most committed to this cause, our fellow workers, Croatian and Italian. ${ }^{38}$

The affirmation of a simple, accessible, uplifting, and optimistic genre like the operetta contributed to the democratization of music and the acceptance of culture in workers' everyday lives, so its connection to the public was established very quickly and easily. Operetta librettos were often intertwined with ironic self-reflection. Its purpose was often to offer a parodied view of social differences. Such content was presented by employing sarcasm and satirical devices to denounce and ridicule the hypocrisy and superficiality of the high social classes, thus providing convenient means to criticize the bourgeoisie and its decadence, which in turn was compatible with the socialist cultural postulates. ${ }^{39}$ The operetta repertoire was sometimes inconsistent in terms of quality and performance, but this did not significantly affect its popularity. In the 1950 s, the theater, the huge success of operettas and drama performances notwithstanding, was faced with many problems, the most serious being the lack of personnel. The theater did not have a permanent director, while the engagement of professionals from another theater represented an excessive expense. Moreover, the size of the ensemble was inadequate, scenographers had to improvize, and re-tailor old settings and costumes, and interpersonal relations were less than satisfying. ${ }^{40}$ Furthermore, political authorities did not provide the ensemble with adequate financial support: faith and love for the socialist country were considered a sufficient stimulus for the theater

38. "Oduševljenje kojim su baš amateri prišli radu na izvedbi ovog djela, upornost i zalaganje koje su pokazivali za vrijeme uvježbavanja i uspjeh dosadašnjih izvedbi, sve to dokazuje kakve se mogućnosti i sposobnosti nalaze u naših radnih ljudi za rad na kulturno-umjetničkom polju, koliko u vokalnoj, toliko i u instrumentalnoj glazbi. Zahvaljujući obilnoj pomoći naše narodne vlasti i stalnoj brizi kod uklanjanja svih poteškoća, Pula postaje grad širokih mogućnosti rada na polju kulture i umjetnosti a u prvim redovima onih koji se zalažu na procvatu kulturnog života Pule nalaze se naši radni ljudi, Hrvati i Talijani." No author, "Prva glazbena predstava s domaćim snagama u Puli" [The first independently organized musical production in Pula], Riječki list (21 December 1949), 3.

39. Moritz Csáky, Ideologie der Operette und Wiener Moderne. Ein kulturhistorischer Essay zur österreichischen Identität (Wien-Köln-Weimar: Böhlau, 1996).

40. Štefan Mlakar "Tri godine rada pulskog kazališta" [Three years of theater in Pula], Riječki list (29 January 1952), 3; No author, "Obnovljeno Narodno kazalište u Puli pred novom sezonom" [The renovated Pula National Theater heading in the new season], Riječki list (19 September 1952), 3. 
members to be willing to selflessly carry out the work they were designated to do, and thus contribute to building the socialist culture, despite all obstacles and financial difficulties.

This is a path toward further affirmation of our fledgling theater. ... It's a path to affirming cultural, artistic, and national relationships among our newly liberated parts of the country and with our cultural centre, with those whose work is an example of the most precious, most enlightening and the most powerful manner of artistic expression. ... It is our highest national and social responsibility, our moral code, to further encourage and strengthen these aspirations, because in this way brotherhood is forged, new insights are gained, giving an incentive to both body and spirit. ${ }^{41}$

Since the production of operettas was very expensive and required a huge amount of resources, in 1956/1957 they were removed from the repertoire and the ensemble was dismissed only a few years after its establishment (Plate 3). ${ }^{42}$

Plate 3 Poster of a performance of Kálmán's operetta Die Csárdásfürstin by the operetta ensemble of the National Theater in Pula

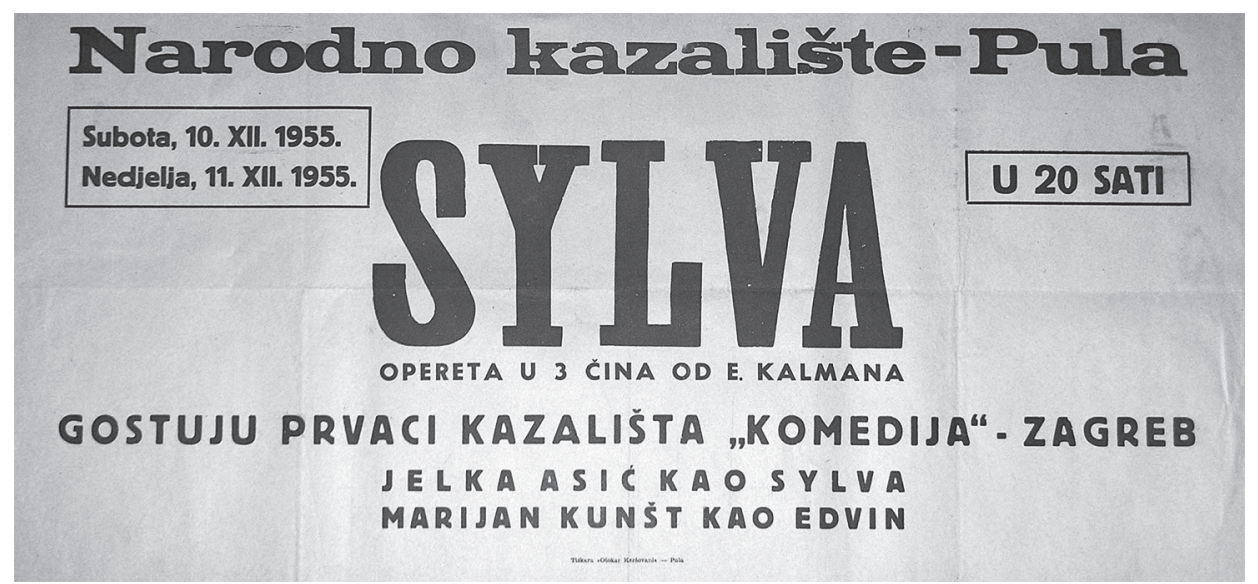

41. "Put je to nove afirmacije tog našeg mladog kazališta. ... to je put kazališno-umjetničkog i kulturno-nacionalnog povezivanja novooslobođenih krajeva sa našim kulturnim središtem, sa predstavnicima našeg najvrjednijeg, najvišeg i najsnažnijeg umjetničkog iživljavanja. ... Naša je opća nacionalna i socijalna dužnost, naš je to moralni zakon, da puteve te vrste umnožimo i učestamo, jer oni kuju bratstvo, oni razotkrivaju nove spoznaje, oni fizički i duhovno osvježuju i probuđuju." No author, "Gostovanje u Pulskom kazalištu" [Guest performance at the Pula theater], Glas Istre (24 June 1955), 4.

42. About closing down of the operetta ensemble, see: No author, "Istarsko narodno kazalište pred alternativom ili-ili. Dinar i kultura" [Istrian National Theater facing the alternative either-or. The Dinar and the culture], Glas Istre (1 September 1961), 5; No author, "Kazališni razgovori neugodni”" [Unpleasant theatrical conversations], Glas Istre (18 January 1963), 5; Mirella Fonio, "La crisi del teatro Istriano," La Voce del Popolo (6 October 1963), 4. 
In the first years after the Second World War, when the population structure was completely transformed, the newly inaugurated authorities wanted to show to the dwellers of the biggest city on the Istrian peninsula, who, during the Fascist occupation, had had a chance to see performances by Italian opera stars $^{43}$ that Yugoslav theaters had competent performers of their own. In the post-war years, the demonstration of national music and performance potential to citizens of the newly annexed parts was an extremely significant issue, so significant funds were allocated to fund performances of Yugoslav guest musicians in Pula.

The political leadership wanted to make opera and ballet music more popular and there was a tendency to make such performances more available to all classes of citizens, especially to workers. Pula had an ideal venue to stage such events the Amphitheater. By having guest ensembles from different parts of the country performing in the Arena, "the brotherhood and unity" (otherwise, one of the most often used Communist political slogans) of all Yugoslav peoples was strengthened, and culture consumption stimulated.

... the closed auditorium, with boxes and restricted admission, clearly reveals its purpose: it was intended for the privileged classes, aristocrats and bourgeois snobs, who came to the performances to show off their gowns and mingle in the foyer in the breaks between the acts. But today, this auditorium of the Pula amphitheater, built for Roman officials and commoners who were thrown "panem and circenses" so as to dwarf any revolutionary idea they might indulge, this auditorium hosts today a wide array of people of all classes, who are increasingly more aware of the value of their socialist homeland, and who genuinely and intensely indulged in the art of theater performance, unconfined by the limits of aristocratic, bourgeois theater. ${ }^{44}$

When Vespasian, according to the legend, built this Amphitheater to provide the Romans with some "cultured" entertainment - gladiator fights, slave fights against wild beasts, in other words, blood baths for the pleasure of patricians -,

43. Including the tenors Beniamino Gigli and Nino Piccaluga, the sopranos Toti Dal Monte and Lina Bruna Rasa, the baritones Giovanni Inghilleri and Carlo Galeffi, as well as the conductors Antonino Votto and Edoardo Vitale. Cf.: Duraković, Pulski glazbeni život u razdoblju fašističke diktature, 175-176.

44. “... zatvoreno gledalište, sa svojim sistemom loža odaje odmah svoje porijeklo: ono je građeno za povlaštene klase, za aristokratske i građanske snobove, koji su dolazili na predstave više zbog toga da pokazuju svoje toalete i da se animiraju između činova u foajeima. Ovdje pak, na ovim izvedbama, širokom otvorenom prostoru u pulskoj Areni, građenom nekada za rimske vlastodršce i za deklasirane mase kojima se, da ih se odaleči od revolucionarnog vrenja davalo 'Panem et circenses,' kruha i igara, na tim ostacima nekadašnje arene, tu su ovih dana zaista bile široke narodne mase, osviješćene i sve više osvješćavane u svojoj socijalističkoj domovini, koje su se u pravom i nepatvorenom oduševljenju - ne sapete u uske okvire zatvorenog aristokratsko-građanskog teatra, predale doživljavanju kazališne umjetnosti.” No author, "Gostovanje Hrvatskog narodnog kazališta iz Zagreba u Puli" [Guest performance of the Zagreb National Theater in Pula], Riječki list (7 June 1949), 3. 
he could not have possibly imagined that one day it will serve a higher purpose of connecting the liberated masses with art. ${ }^{45}$

As a result, guest performances of Yugoslav musical stage artists were generously supported financially. Thus, from 1949 to 1955, opera ensembles from Zagreb, Belgrade, Ljubljana, and Rijeka performed in Pula and operas by Giuseppe Verdi, George Bizet, Giacomo Puccini, Richard Wagner, Gioachino Rossini, as well as by prominent Yugoslav composers like Jakov Gotovac, ${ }^{46}$ Stevan Hristić, ${ }^{47}$ and Ivan Zajc ${ }^{48}$ formed the repertoire (see Plate 4). ${ }^{49}$

The available archival sources contain very few documents describing the reactions of state and party organs in charge of culture and musical stage performances. However, daily newspaper articles, which surely very closely reflected their thoughts, constantly appealed to workers to visit opera performances. ${ }^{50}$

45. "Kad je Vespazijan, kako kaže legenda, gradio tu arenu želeći vladajućim rimskim krugovima pružiti 'kulturnu' zabavu- gladijatorske igre, borbe robova sa zvijerima, dakle, prolijevanje krvi u potocima za užitak patricija - nije mogao ni sanjati da će ona jednoga dana poslužiti velikoj svrsi povezivanja oslobođenih masa naroda s umjetnošću." Ivo Tijardović, "Posjet opernih umjetnika narodu Istre" [Opera performers visit the people of Istria], Vjesnik (19 June 1949), 3.

46. Croatian composer and conductor Jakov Gotovac (1895-1982) went to school in Split and Vienna, and started his career in Śibenik in 1922 as conductor of the Philharmonic Society. During his career as a conductor (1923-1957), he was also the director of the Zagreb Opera (1943) and choirmaster of numerous vocal ensembles. He was a prominent representative of the national school within twentieth-century Croatian music. He was an academic and an honorary member of the Croatian National Theater, and became internationally famous with his comic opera Ero s onoga svijeta [Ero the Joker] (1933-1935). Ero was translated into nine languages and staged in numerous opera houses. Jakov is also famous for his Symphonic Reel (1926), his choir Koleda (1936), his opera Morana (1930), his stage music for Gundulić's Dubravka (1929), and for solo songs accompanied by orchestra and piano, etc. See more: http://hbl.lzmk.hr/clanak.aspx?id=7314; http://proleksis. lzmk.hr/24047/ (last accessed on 13 September 2017).

47. Serbian composer, conductor, teacher, and music writer Hristić Stevan (1885-1958) studied in Leipzig between 1904 and 1908. He began his career as a conductor at the National Theater in Belgrade. He was the founder and the first principal conductor of the Belgrade Philharmonic (1923-1934), conductor at the Belgrade Opera House (director: 1925-1935), and one of the founders and first professors of the Belgrade Music Academy (professor of composition: 1937-1950, president: 1943-1944). He is the author of the ballet Ohridska legenda (1947), the opera Suton (1925), the oratorio Vaskrsenje (1912) and many choirs and songs. Hristić's musical language is characterized by melodic inventiveness, colourful orchestration, late Romantic and partially impressionistic harmonies. Cf. http://www.enciklopedija.hr/natuknica.aspx?id=26348 (last accessed 29 October 2017).

48. Croatian composer, conductor, and teacher Ivan Zajc (1832-1914) was educated at the Milan conservatory. After returning to his hometown of Rijeka, he worked as a conductor and concertmaster of the City Theater Orchestra, and taught string instruments in the Philharmonic Society. In 1862, he moved to Vienna where he pursued a successful career as operetta writer. In 1870, he came to live in Zagreb where he became director and conductor of the first standing Croatian Opera and head of the music school of the Music Institute. He was head of the Opera until 1889 when it was abolished for the first time, and managed the school until his retirement. He implemented a thorough reorganization of the Opera and significantly contributed to the training of the ensemble that performed about 50 operas and a dozen operettas during the 19 years of Zajc's management. As a composer, Zajc has a rich lifework. His opera Nikola Šbić Zrinjski is one of the best and most performed national operas, and his manuscript legacy consists of over a thousand works. See http://www.enciklopedija.hr/ natuknica.aspx?id=66730; http://db.nsk.hr/HeritageDetails.aspx?id=831 (last accessed on 13 September 2017).

49. Lada Duraković, "Ususret narodu II: Prve poslijeratne operne sezone u pulskoj Areni 1949-1952." [Meeting the people II: The first post-war operatic seasons in the Arena of Pula (1949-1952)], Arti musices 38/2 (2007) 217-231.

50. The daily newspapers Glas Istre and La Voce del Popolo provided media coverage of these opera performances. 
Plate 4 Opera seasons in the Arena: poster of a visit of the Rijeka Opera in 1952

\section{TEATRO DEL POPOLO DI FIUME} STAGIONE LIRICA $A R E N A, P O L A$

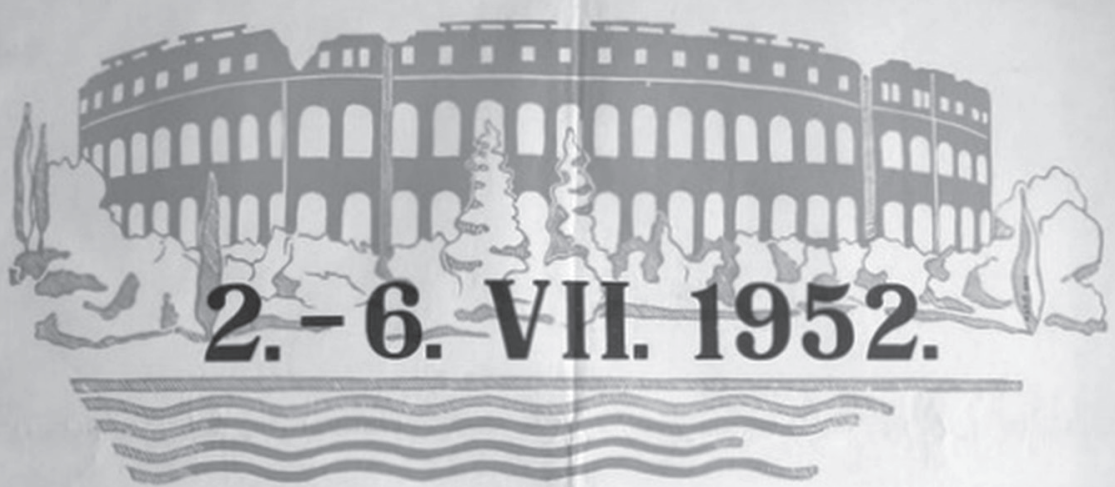

2. VII. z a J c: NIKOLA ŠUBIĆ ZRINSKI

3. VII. VERDI: R I G O L E T T O

4. VII. BIZET: $C$ A R M E N

5. vil. z A J c: NIKOLA ŠUBIĆ ZRINSKI

6. VII. PUCCINI: $L A B O H E$ REGIST ANTON KOREN, BERISLAV BRAJKOVIC DROENT STANKO SIMUNIC
ZDENKO PEHARDA, VLADIMIR BENIC SCENOGAR ANTUN ŻUNIC BERISLAV DEZELIC, SERGEJ KUCINSKI COREOGRAFO OLGA ORLOVA

SOLIST ŚTEFANUA LENKOVIC, ZUTA BUTKOVIC, CARMEN VILOVIC, IRMA DEMORIS, NADA AUER, NEVENRA TOMAŚC SOLSTIKA STEANIJA LENKOVIC, ZLATA BUTOUC, CARMEN VILOVIC, ROMNIK, JOSIP MATELJAN, SANDI BOSTIJANCIC BLANKA ZEC, VLADIMIR RUŻDJAK $k$ g. JOSIP SUTEJ, OSKAR ZORNIK, JOSIP MA SCIACQUL FRANIO GODEC MILAN PIHLER, BRANKO MEDANIC, ENZO SERINL, KONRAD OROZIN, DANIE SCIACOUL, INIZIO ORE 20:30. - PREZZI DINGRESSO: 70. 60. 50 E 20 DINARI

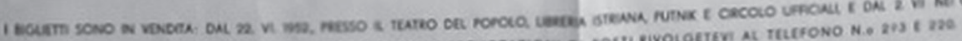


In spite of difficult financial and cultural circumstances, in the first post-war years many guest performers performed in Pula, such as the most prominent Yugoslav composers and conductors Boris Papandopulo, ${ }^{51}$ Jakov Gotovac, Stevan Hristić, and ballet dancers Ana Roje and Oskar Harmoš. Among these were also vocal artists, such as Vilma Nožinić, Marijana Radev, Josip Gostić, Tomislav Neralić, Miroslav Čangalović, and Vladimir Ruždjak, who proved their artistic merit at the time, or shortly after, on the most important theaters in the world, such as La Scala in Milan, the New York Metropolitan Opera, the London Covent Garden, and the Vienna State Opera. This clearly shows the fact that Pula citizens had the chance to meet the most renowned music artists in the country. Political authorities should be given credit for this because, without their influence, it would have been difficult to fund performances of guest opera ensembles in an impoverished province such as Istria was in those days.

$$
* * *
$$

The most prominent trait of the post-war period in Pula, as well as in other parts of Croatia and Yugoslavia, is the tendency to promote musical art and increase the scope of its reception. The newly formed Communist government used arts to ensure enforcement of particular ideas. Musical art was, hence, both systematically and purposefully manipulated and financially supported. As an important factor in societal transformation, music was to be available to the entire population, so as to reduce cultural inequality. In the early post-war years, it was believed that indeed all music programmes - festivals, concerts as well as opera and ballet performances - would soon be attended by working class people, and that in due course of time, this would result in the development of a particular, socialist, proletarian music production.

However, within the impoverished economy of the city of Pula, the working class was not particularly interested in such pursuits. Lower classes did not have a

51. Croatian composer and conductor Boris Papandopulo (1906-1991) studied music composition in Zagreb and conducting in Vienna. He was a choirmaster in Zagreb, conductor of the Social Orchestra of the Croatian Music Institute, conductor and professor at a music school in Split, since 1940 a conductor of the Opera and the Symphonic Orchestra of Radio Zagreb, and since 1945 the director and conductor of the Opera in Rije$\mathrm{ka}$, and also the opera conductor in Sarajevo, Zagreb, and Split. For a while, he was a standing guest conductor of the Opera in Cairo. He was involved in music criticism and opinion journalism. He wrote more than 400 musical pieces, including symphonies, symphonic poems, overtures, divertimentos, suites, sonatas, music for string instruments, ten concerts and concert music for various instruments accompanied by orchestra, numerous pieces for various chamber ensembles, pieces for solo instruments, a dozen compositions for solo voices accompanied by various instrumental ensembles. His work also includes various larger vocal-instrumental pieces (some twenty cantatas) and numerous choirs. For the music scene, he wrote eight operas, some fifteen ballets, plays and melodramas, as well as theater and film music, several arrangements and instrumentations, an oratory, a mass, and also battle and mass songs. He published a number of studies, articles and critiques. He was a regular member of the Croatian Academy of Sciences and Arts, and a winner of several awards. See more: http://proleksis.lzmk.hr/40534/ (last accessed on 13 September 2017). 
habit of attending such events, as classical music was something far removed from life as they knew it. The better educated members of society, on the other hand, had a strong urban background. The most popular shows and concerts were those featuring renowned artists. Generally, the audience found foreign, Western European productions more appealing than domestic ones, especially when it came to opera performances.

The discrepancy between high art and broader masses could not have possibly been overcome quickly and easily. It is beyond doubt, however, that the efforts vested in cultural education of all layers of society in Pula had a huge positive impact. A music school was established and attended by a remarkable number of children. Enthusiastic participation in cultural-artistic associations resulted in advancement of music amateurism, which is to this day a hallmark of the city's music life. Music programmes were abundant, and even though the underlying reason for such proliferation was raising the new, broadly educated socialist man, ideological inputs as such were only latently present, or not at all. This allowed the citizens of Pula to become acquainted with classical music, and in some cases, to eventually change the perception of classical music as an exclusive privilege of only a single class. 